\title{
MODEL PEMBELAJARAN KOOPERATIF TIPE STAD PADA MATA MATA PELAJARAN MEMAHAMI PENGUKURAN KOMPONEN ELEKTRONIKA
}

\author{
Hambali $^{1}$, Fivia Eliza ${ }^{1}$, Yudi Andika ${ }^{*}$ \\ ${ }^{1}$ Jurusan Teknik Elektro, Fakultas Teknik, Universitas Negeri Padang \\ *Email: yudiandika9@gmail.com
}

\begin{abstract}
Abstrak- Penelitian ini membahas tentang penerapan model pembelajaran kooperatif tipe STAD pada Mata Pelajaran Memahami Pengukuran Komponen Elektronika di SMK Muhammadiyah 1 Padang. Tujuan penelitian ini adalah untuk mengetahui besarnya ketuntasan hasil belajar siswa setelah menggunakan model pembelajaran kooperatif tipe $S T A D$. Jenis penelitian ini menggunakan eksperimen bebas (pre eksprimental). Subjek pada penelitian ini adalah siswa kelas X TITL 1 SMK Muhammadiyah 1 Padang yang terdaftar pada tahun ajaran 2016/2017 yang terdiri dari 32 orang siswa. Metode pengumpulan data dengan menggunakan tes hasil belajar berupa tes objektif yang terdiri dari pretest, kuis sebanyak 3 kali serta posttest yang sudah dilakukan uji coba soal sebelumnya. Data yang diperoleh tersebut dianalisis menggunakan rumus ketuntasan belajar siswa Sedangkan untuk menentukan Skor kemajuan Individu sebagai syarat penentuan nilai kelompok STAD dilakukan kuis setiap akhir pembelajaran. Hasil penelitian ditemukan bahwa rata-rata nilai pretest sebelum penerapan pembelajaran kooperatif tipe STAD sebesar 61,09 dan rata-rata nilai posttest setelah penerapan pembelajaran kooperatif tipe $S T A D$ sebesar 83,56. Dengan demikian dapat disimpulkan bahwa penerapan model pembelajaran kooperatif tipe $S T A D$ dapat meningkatkan ketuntasan belajar siswa pada mata pelajaran Memahami Pengukuran Komponen Elektronika di SMK Muhammadiyah 1 Padang.
\end{abstract}

Kata Kunci: STAD, Ketuntasan Belajar, Memahami Pengukuran Komponen Elektronika

\begin{abstract}
This research aimed implementating STAD cooperative learning model with subject measurement of electronic components in SMK Muhammadiyah 1 Padang. The purpose of research was increase student's learning outcome after using STAD cooperative learning. This research was a pre eksperimental design. The subject of this research is student classs X TITL 1 SMK Muhammadiyah 1 Padang in the academic years 2016/2017 that consisting of 32 students. the data collected with objective test, three time the quiz and posttest tested previously. date were. The date result showed the average value of pretest before implementation STAD cooperative learning in 61,09 and the average value posttest after the implementation STAD cooperative learning in 83,56. It can be concluded that the implementation STAD cooperative learning model can improve students' learning outcome of on the subject measurements of electronic components in SMK Muhammadiyah 1 Padang.
\end{abstract}

Key word: STAD, Learning Outcome, Understanding Measurements of Electronic Component

Copyright @ 2017 INVOTEK. All rights reserved

\section{PENDAHULUAN}

Perkembangan dunia pendidikan tidak terlepas dari proses pembelajaran yang berlangsung secara formal maupun non formal. Kualitas pendidikan merupakan aspek terpenting dalam upaya kemajuan pendidikan. Pendidikan diyakini dapat mendorong memaksimalkan generasi masa dalam menghadapi dan menyelesaikan setiap permasalahan yang dihadapi di era globalisasi. Peraturan menteri pendidikan nasional No. 41 tahun 2007 menuntut agar proses pembelajaran pada setiap satuan pendidikan dasar dan menengah harus interaktif, inspiratif,
\end{abstract}

menyenangkan, menantang, dan memotivasi siswa untuk berpartisipasi aktif serta memberikan ruang yang cukup bagi prakarsa, kreativitas, dan kemandirian sesuai dengan bakat, minat dan perkembangan fisik serta psikologi siswa.

Sekolah Menengah Kejuruan (SMK) merupakan salah satu lembaga pendidikan formal dalam bidang teknik yang merupakan integral dari sistem pendidikan teknologi dan kejuruan di Indonesia. SMK Muhammadiyah 1 Padang juga ikut serta dalam melaksanakan berbagai aktivitas dan kegiatan pendidikan formal dengan tujuan mewujudkan ketercapaian lulusan yang 
berkualitas. Salah satu program keahlian yang terdapat di SMK Muhammadiyah 1 Padang adalah Teknik Instalasi Tenaga Listrik (TITL). Salah satu mata pelajaran produktif yang sangat penting untuk siswa TITL adalah Memahami Pengukuran Komponen Elektronika (MPKE).

Berdasarkan studi pendahuluan di lapangan melalui observasi dan wawancara pada bulan November 2016 dengan guru bidang studi MPKE dijumpai beberapa fenomena yang menghambat tercapainya tujuan pembelajaran. Hal ini disebabkan kurangnya interaksi antara guru dengan siswa sehingga pembelajaran jadi monoton. Dalam memahami materi yang diberikan guru, siswa sering kesulitan untuk belajar secara mandiri. Banyak diantara siswa yang tidak mau berbagi pengetahuan dengan teman sekelasnya. Akibatnya proses pembelajaran menjadi terhambat dan tujuan pembelajaran tidak sepenuhnya tercapai serta akan berdampak salah satunya pada presentase ketuntasan siswa yang masih rendah. Setiap siswa dikatakan tuntas belajarnya (ketuntasan Individu) jika proporsi jawaban benar siswa $\geq 65 \%$. Suatu kelas dikatakan tuntas belajarnya (ketuntasan klasikal) jika $\geq 85 \%$ siswa dikelas tersebut telah tuntas belajarnya [5]. Jika pembelajaran dilaksanakan secara berkelompok, tentu permasalahan ini bisa diatasi. Hubungan kerjasama yang terjalin dengan baik, serta akan saling membantu mengatasi kesulitan dalam belajar.

Pembelajaran kooperatif adalah model pembelajaran yang mengutamakan kerja sama untuk mencapai tujuan pembelajaran [1]. Dengan adanya penerapan pembelajaran kooperatif ini diharapkan siswa biasa belajar secara berkelompok. Proses pembelajaran akan lebih aktif dan efektif, rasa saling menghargai pendapat teman sekelompok, serta bersikap terbuka dalam menerima kritik dan saran dari kelompok lain.

Penelitian ini membahas tentang penerapan model pembelajaran kooperatif tipe $S T A D$ pada mata pelajaran menggunakan Pengukuran Komponen Elektronika (MPKE) di kelas X TITL SMK Muhammadiyah 1 Padang. Pada kompetensi dasar Memahami peralatan ukur listrik dan elektronika dengan menggunakan Model pembelajaran kooperatif tipe Student TeamsAchievement Division (STAD) atau Divisi Pencapaian-Kelompok Siswa.

Tipe STAD merupakan salah satu metode pembelajaran kooperatif yang paling sederhana, dan merupakan model yang paling baik untuk pemulaaan bagi para guru yang baru menggunakan pendekatan kooperatif [4]. Tipe STAD yang dikembangkan oleh Slavin ini lebih menekankan pada akivitas dan interaksi antara siswa untuk saling memotivasi dan saling membantu dalam menguasai pelajaran untuk memperoleh hasil belajar yang maksimal. Model pembelajaran ini memungkinkan siswa memahami mata pelajaran MPKE secara berkelompok sehingga siswa dapat berdiskusi dengan siswa yang lainnya yang lebih memahami pelajaran tersebut, sehingga pelajaran berjalan lebih efektif. Tujuan penelitian ini adalah untuk mengetahui besarnya ketuntasan hasil belajar siswa menggunakan model pembelajaran kooperatif tipe $S T A D$ pada mata pelajaran Memahami Pengukuran Komponen Elektronika kelas X TITL di SMK Muhammadiyah 1 Padang.

\section{METODE PENELITIAN}

Jenis penelitian yang digunakan adalah menggunakan eksperimen bebas (pre eksperimental) dengan desain One Group PretestPosttest Design yaitu metode penelitian yang dilakukan dengan pengontrolan yang sesuai dengan kondisi yang ada (situsional). Penelitian ini menggunakan satu kelas dan dilaksanakan 6 kali pertemuan dengan alokasi waktu 3 x 45 menit, dimana pretest dilakukan pada pertemuan pertama sebelum dilakasanakan perlakuan untuk melihat hasil belajar siswa pada KD yang ingin diberikan perlakuan yaitu pada kompetensi dasar memahami peralatan ukur listrik dan elektronika [6].

Selanjutnya pada pertemuan berikutnya dilakukan pembahasan materi dengan menggunakan Model Pembelajaran Kooperatif Tipe STAD. Setiap akhir pertemuan dilakukan kuis untuk skor perkembangan individual pada STAD. Pertemuan terakhir (ke enam) dilakukan posttest untuk mengetahui ketuntasan belajar siswa setelah pembelajaran dilakukan dengan Model Pembelajaran Kooperatif Tipe STAD. Penelitian ini akan melihat ketuntasan hasil belajar siswa setiap dilaksanakan evaluasi pada proses pembelajaran. Rancangan penelitian ini dapat dilihat pada Tabel 2.1.

Tabel 2.1. Rancangan Penelitian

\begin{tabular}{|c|c|c|}
\hline Pretest & Treatment & Postest \\
\hline $\mathrm{T}_{1}$ & $\mathrm{X}$ & $\mathrm{T}_{2}$ \\
\hline
\end{tabular}

Sumber : Sugiyono, 2015:111

Keterangan:

$\mathrm{T}_{1}=$ Pretest

$\mathrm{T}_{2}=$ Posttest

$\mathrm{X}=$ Perlakuan pada kelas eksperimen (Model

Pembelajaran Kooperatif Tipe STAD) 
Subjek dari penelitian yang akan dilakukan adalah siswa kelas X TITL SMK Muhammadiyah 1 Padang Tahun ajaran 2016/2017 yang terdiri atas 32 orang di kelas TITL 1 dan 32 orang di kelas TITL 2. Penelitian ini menggunakan 1 kelas eksperimen dan 1 kelas uji coba. Pemilihan kelas dilakukan dengan menggunakan Nilai akhir semester mata pelajaran sebelumnya yang berkaitan dengan mata pelajaran MPKE yaitu nilai akhir semester mata pelajaran Menggunakan Hasil pengukuran Listrik (MHPL) dengan menggunakan analisis uji t. Setelah kedua kelas bisa dijadikan sebagai subjek penelitian, maka penentuan kelas dilakukan secara acak.

Dalam analisis uji $\mathrm{t}$ yang dilakukan didapatkan bahwa $\mathrm{t}$ hitung $<\mathrm{t}$ tabel atau $0,054<$ 1,9993. Hal ini menjunjukkan tidak terdapat perbedaan kemampuan kedua kelas yang signifikan secara statistik. Maka kelas X TITL 1 terpilih sebagai kelas eksperimen dan kelas $\mathrm{X}$ TITL 2 sebagai kelas uji coba soal. Soal tes disusun berdasarkan materi dan tujuan yang ingin dicapai dalam pembelajaran berdasarkan kurikulum. Instrumen yang digunakan sebelumnya telah di validasi terlebih dahulu dan dilakukan uji validitas, reliabilitas, tingkat kesukaran, dan daya beda soal.

Uji coba soal dilakukan pada kelas X TITL 2 tahun ajaran 2016-2017. Uji coba instrument soal mencangkup uji validitas, reliabilitas, tingkat kesukaran, dan daya beda soal. Dari perhitungan validitas,reliabilitas, taraf kesukaran dan daya beda pada uji coba soal pretest dari 35 diperoleh 28 soal layak untuk digunakan dan 7 soal tidak layak untuk digunakan pada subjek penelitian. Pada soal uji coba posttest, dari 35 soal diperoleh 28 soal layak untuk digunakan dan 7 soal tidak layak untuk digunakan.

\section{HASIL DAN PEMBAHASAN}

\section{Hasil}

a. Deskripsi Data

Data pada hasil penelitian ini merupakan data hasil belajar Memahami Pengukuran Komponen Elektronika (MPKE) pada kelas X TITL 1 SMK Muhammadiyah 1 Padang yang berjumlah 32 orang. Data awal penelitiaan ini diperoleh dari hasil pretest. Nilai pretest siswa yang diperoleh terdapat pada rentang 43-83. Data akhir diperoleh setelah kelas diberikan perlakuan dengan pembelajaran menggunakan model pembelajaran kooperatif tipe $S T A D$ adalah nilai posttest . Nilai yang didapat siswa pada tes akhir ini memiliki rentang 70-97. Berdasarkan analisis data pretest, diperoleh nilai rata-rata $(\bar{X})$ dan simpangan baku (s) siswa sebagaimana terlihat pada tabel 3.1.

Tabel 3.1. Rangkuman Nilai pretest X TITL 1

\begin{tabular}{|c|c|c|c|c|c|}
\hline Kelas & $\begin{array}{c}\text { Nilai } \\
\text { Tertinggi }\end{array}$ & $\begin{array}{c}\text { Nilai } \\
\text { Terendah }\end{array}$ & $\bar{X}$ & $\mathrm{~N}$ & $\mathrm{~s}$ \\
\hline $\begin{array}{c}\mathrm{X} \\
\text { TITL } \\
1\end{array}$ & 83 & 43 & 61,09 & 32 & 10,68 \\
\hline
\end{tabular}

Sebaran data frekuensi dapat terlihat pada tabel 3.2. Berdasarkan tabel 3.2. dapat terlihat bahwa masih banyak siswa yang berada pada interval nilai 43-77. Gambaran distribusi frekuensinya akan lebih jelas terlihat pada gambar 3.1 .

Tabel 3.2. Distribusi Frekuensi Pretest

\begin{tabular}{|c|c|c|}
\hline No. & Kelas Interval & $\mathrm{f}$ \\
\hline 1 & $43-49$ & 4 \\
\hline 2 & $50-56$ & 8 \\
\hline 3 & $57-63$ & 9 \\
\hline 4 & $64-70$ & 5 \\
\hline 5 & $71-77$ & 2 \\
\hline 6 & $78-84$ & 4 \\
\hline \multicolumn{2}{|c|}{ Jumlah } & 32 \\
\hline
\end{tabular}

Gambar 3.1 Grafik Nilai Pretest

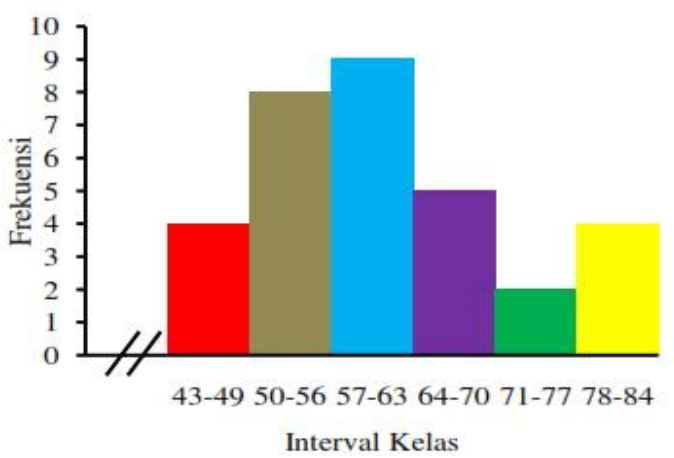

Uji normalitas dilakukan untuk melihat apakah data dari kelas subjek penelitian berdistribusi normal, maka dilakukan uji normalistas dengan menggunakan metode chikuadrat dengan perhitungan manual. Pengujian diperoleh dari perbandingan harga $X_{\text {hitung }}^{2}$ dengan nilai $X_{\text {tabel }}^{2}$ untuk $\alpha=0,05$ dan derajat kebebasan (dk) $\equiv 32-1=31$, Perhitungan uji normalitas terdapat pada tabel 3.3. Pada tabel 3.3. dapat dilihat bahwa perhitungan uji normalitas pretest didapatkan $\chi 2$ hitung $<\chi 2$ tabel, artinya bahwa data yang 
didapatkan dari subjek penelitian ini berdistribusi normal.

Tabel 3.3. Rangkuman Uji Normalitas Pretest

\begin{tabular}{|c|c|c|c|c|}
\hline $\begin{array}{c}\text { Nilai } \\
\text { Tertinggi }\end{array}$ & $\begin{array}{c}\text { Nilai } \\
\text { Terendah }\end{array}$ & $\bar{X}$ & $\mathrm{~N}$ & $\mathrm{~S}$ \\
\hline 97 & 70 & 83,56 & 32 & 6,77 \\
\hline
\end{tabular}

Penelitian yang telah dilaksanakan merupakan Model Pembelajaran Kooperatif Tipe STAD. Dalam STAD, Terdapat kuis atau evauasi yang akan dilaksanakan setiap akhir dari proses pembelajaran untuk melihat skor kemajuan individual yang akan menentukan skor kelompok. Terdapat 3 kali kuis dilaksanakan Sedangkan posttest dijadikan sebagai skor akhir siswa. Berdasakan analisis data kuis diperoleh nilai ratarata ( $\left.{ }^{8}\right)$ dan simpangan baku (s) siswa sebagaimana terlihat pada tabel 3.4.

Tabel 3.4. Rangkuman Nilai Kuis

\begin{tabular}{|c|c|c|c|c|c|}
\hline & $\begin{array}{c}\text { Nilai } \\
\text { Tertinggi }\end{array}$ & $\begin{array}{c}\text { Nilai } \\
\text { Terendah }\end{array}$ & $\bar{X}$ & $\mathrm{~N}$ & $\mathrm{~s}$ \\
\hline Kuis 1 & 90 & 50 & 69,1 & 32 & 9,81 \\
\hline Kuis 2 & 85 & 60 & 74,8 & 32 & 6,95 \\
\hline Kuis 3 & 93 & 65 & 79,3 & 32 & 5,95 \\
\hline
\end{tabular}

Pada Tabel 3.5 dapat dilihat bahwa perhitungan uji normalitas Kuis 1-3 yang dijadikan sebagai skor kemajuan individual yang menentukan skor kelompok pembelajran STAD, didapatkan $\chi^{2}$ hitung $<\chi^{2}$ tabel, artinya bahwa data yang didapatkan dari subjek penelitian ini berdistribusi normal.

Tabel 3.5. Rangkuman Uji Normalitas Kuis

\begin{tabular}{|c|c|c|c|c|}
\hline & $\mathrm{N}$ & $\mathrm{z}_{\mathrm{x}}$ & $\ddot{*} \because b e l$ & Distribusi \\
\hline Kuis 1 & 32 & 11,66 & 44,97 & Normal \\
\hline Kuis 2 & 32 & 4,48 & 44,97 & Normal \\
\hline Kuis 3 & 32 & 1,51 & 44,97 & Normal \\
\hline
\end{tabular}

Pada penelitian ini, nilai posttest dijadikan sebagai data nilai akhir siswa. Berdasarkan analisis data posttest, diperoleh nilai rata-rata $(\bar{X})$ dan simpangan baku (s) siswa sebagaimana terlihat pada tabel 3.6.

Tabel 3.6. Rangkuman Nilai Posttest

\begin{tabular}{|c|c|c|c|c|}
\hline $\begin{array}{c}\text { Nilai } \\
\text { Tertinggi }\end{array}$ & $\begin{array}{c}\text { Nilai } \\
\text { Terendah }\end{array}$ & $\bar{X}$ & $\mathrm{~N}$ & $\mathrm{~S}$ \\
\hline 97 & 70 & 83,56 & 32 & 6,77 \\
\hline
\end{tabular}

Tabel 3.7. Distribusi Frekuensi Posttest

\begin{tabular}{|c|c|c|}
\hline No. & $\begin{array}{c}\text { Kelas } \\
\text { Interval }\end{array}$ & $\mathrm{f}$ \\
\hline 1 & $70-74$ & 3 \\
\hline 2 & $75-79$ & 6 \\
\hline 3 & $80-84$ & 9 \\
\hline 4 & $85-89$ & 8 \\
\hline 5 & $90-94$ & 4 \\
\hline 6 & $95-99$ & 2 \\
\hline \multicolumn{2}{|c|}{ Jumlah } & $\mathbf{3 2}$ \\
\hline
\end{tabular}

Berdasarkan tabel 3.7. Dapat dilihat bahwa frekuensi terbanyak dicapai siswa pada interval nilai 80-84. Gambaran distribusi frekuensinya akan lebih jelas terlihat pada grafik berikut.

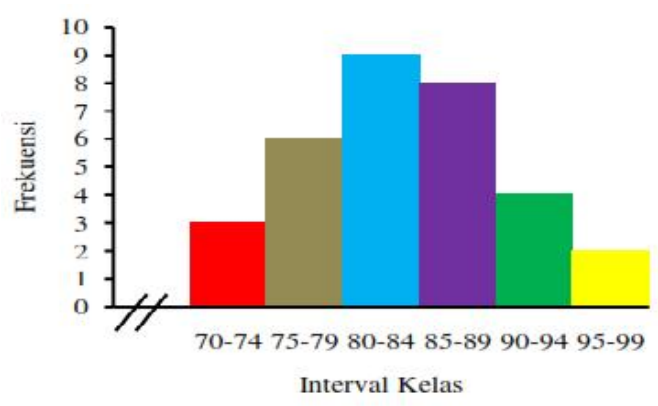

Gambar 3.2. Grafik Nilai Posttest

Tabel 3.8. Rangkuman Uji Normalitas Posttest

\begin{tabular}{|c|c|c|c|}
\hline $\mathrm{N}$ & $\ldots$ & $\ldots$ & Distribusi \\
\hline 32 & 2,19 & 44,97 & Normal \\
\hline
\end{tabular}

Pada tabel 3.8. dapat dilihat bahwa perhitungan uji normalitas posttest didapatkan $\chi 2$ hitung $<\chi^{2}$ tabel, artinya bahwa data yang didapatkan dari subjek penelitian ini berdistribusi normal.

\section{b. Ketuntasan Belajar}

Siswa dikatakan tuntas belajarnya apabila proporsi jawaban benar siswa $\geq 65 \%$. Pada pretest terdapat 19 orang siswa yang jawaban benarnya $\geq$ 65 dan 13 orang siswa dengan jawaban $\$ 65$ dengan persentase $60 \%$ dapat dikatakan ketuntasan belajar siswa belum mencapai $\geq 65 \%$. Pada kuis 1 terdapat 21 orang siswa yang jawaban benarnya $\geq 65$ dan 11 orang siswa dengan jawaban $\$ 65$ dengan persentase $66 \%$. Pada kuis 2 terdapat 31 orang siswa yang jawaban benarnya $\geq 65$ dan 1 orang siswa dengan jawaban $\$ 65$ dengan persentase 96\%. Pada kuis 3 terdapat 32 orang siswa yang jawaban benarnya $\geq 65$ dengan persentase $100 \%$. 
Pada posttest terdapat 32 orang siswa yang jawaban benarnya $\geq 65$ dengan persentase $100 \%$. Sehingga dapat dikatakan bahwa pada kuis 1,2,3 dan posttest siswa telah mencapai proporsi jawaban benar individu siswa.

Dari 32 orang siswa, pada nilai pretest, proporsi nilai siswa yang besaratau sama dengan $\mathrm{KKM}=\geq$ 80 adalah 4 orang dan 80 sebanyak 28 orang dengan persentase ketuntasan kelas $12,5 \%$. Pada nilai kuis 1 , proporsi nilai siswa $\geq 80$ adalah 12 orang dan 80 sebanyak 20 orang dengan persentase ketuntasan kelas 37,5\%. Pada nilai kuis 2 , proporsi nilai siswa $\geq 80$ adalah 10 orang dan 80 sebanyak 20 orang dengan persentase ketuntasan kelas 31,25\%. Pada nilai kuis 3, proporsi nilai siswa $\geq 80$ adalah 16 orang dan $\quad 80$ sebanyak 16 orang dengan persentase ketuntasan kelas $50 \%$. Pada nilai posttest, proporsi nilai siswa $\geq 80$ adalah 23 orang dan 80 sebanyak 9 orang dengan persentase ketuntasan kelas $72 \%$.. Dengan demikian, terdapat peningkatan ketuntasan hasil belajar siswa setelah proses pembelajaran dilaksanakan dengan menggunakan Model Pembelajaran Kooperatif Tipe $S T A D$.

\section{Pembahasan}

Penelitian ini menggunakan persentase ketuntasan hasil untuk melihat peningkatan hasil belajar siswa. Berdasarkan hasil pretest diperoleh nilai rata-rata hasil pretest sebesar $=61,44$. Kemudian dilakukan uji normalitas dan didapat $\chi 2$ hitung $<\chi_{2}$ tabel atau $10,71<44,97$ dapat disimpulkan bahwa data hasil pretest berdistribusi normal. Setelah pretest dilaksanakan, selanjutnya pada subjek penelitian dilaksanakan pembelajaran dengan Model Pembelajaran Kooperatif Tipe STAD. Dengan 4 kali pertemuan selama 4 Minggu.

Model Pembelajaran Kooperatif Tipe STAD dalam proses pembelajarannya Terdapat kuis atau evaluasi yang akan dilaksanakan setiap akhir dari proses. Terdapat 3 kali kuis dilaksanakan dan dalam penelitian ini. Setelah 4 minggu proses pembelajaran dengan menggunakan Model Pembelajaran Kooperatif Tipe STAD dilaksanakan tes Akhir (Posttest). Dari hasil posttest diperoleh rata-rata nilai hasil posttest sebesar $=82,81$. Kemudian dilakukan uji normalitas dan didapat $\chi_{\text {hitung }}^{2} \chi^{2}$ tabel atau $1,67<44,97$ dapat disimpulkan bahwa data hasil posttest berdistribusi normal.

Langkah selanjutnya, untuk melihat persentase ketuntasan hasil belajar siswa setelah dilaksanakan proses pembelajaran dengan menggunakan Model Pembelajaran Kooperatif
Tipe STAD. Dengan menggunakan rumus ketuntasan hasil belajar, dari hasil perhitungan didapatkan 9 siswa mendapatan nilai dibawah ketuntasan minimum dan 23 siswa mendapatkan nilai sama dan diatas kriteria ketuntasan minimum kelas. Hasil perhitungan persentase ketuntasan dari $12,5 \%$ dari nilai pretest meningkat pada kuis 1 dengan persentase $37,5 \%$, pada kuis 2 dengan presentase $31,25 \%$, pada kuis 3 dengan presentase $50 \%$ dan padan posttest dengan presentase peningkatan ketuntasan siswa mencapai $72 \%$. Sehingga keseluruhan siswa meningkat hasil belajarnya dengan skala yang berbeda.

Berdasarkan penelitian yang dilakukan, dapat disimpulkan bahwa terdapat peningkatan persentase hasil belajar siswa setelah menggunakan Model Pembelajaran Kooperatif Tipe STAD pada mata pelajaran memahami Pengukuran Komponen Elektronika di SMK Muhammadiyah 1 Padang. Adanya interksi antara sesama anggota kelompok dengan dilaksanakannya diskusi kelompok. Pembelajaran Kooperatif Tipe $S T A D$ ini membuat siswa bertanggungjawab terhadap anggota kelompok belajar, hal ini dikarenakan penilaian akhir hasil pembelajaran dinilai berdasarkan kemampuan belajar setiap anggota kelompok. Kesimpulan akhir dalam proses pembelajaran dengan menggunakan Model Pembeljaran Kooperatif Tipe STAD dapat meningkatkan hasil belajar dan pemahaman siswa pada mata pelajaran Memahami Pengukuran Komponen Elektronika di kelas X TITL 1 SMK Muhammadiyah 1 Padang.

\section{KESIMPULAN DAN SARAN}

\section{Kesimpulan}

Berdasarkan analisis data penelitian yang telah dilakukan, dapat disimpulkan bahwa terdapat peningkatan hasil belajar siswa dengan menerapkan Model pembe lajran Koperatif Tipe STAD. Pada mata pelajaran Memahami Pengu kuran Komponen Elektronika di SMK Muhammadiyah 1 Padang dengan penjelasan sebagai berikut:

1. Rata-rata kemampuan awal siswa yang dilihat dari nilai pretest sebelum dilakukan pembelajaran dengan menggunakan Model pembelajaran Koperatif Tipe STAD adalah 61,09 yang masih belum mencapai ketuntasan mimimum dengan persentase pencapaian sebesar 12,5\%. Kemudian setelah dilaksanakan pembelajaran dengan Model pembelajran Koperatif Tipe $S T A D$ didapatkan rata-rata nilai posttest siswa sebesar 83,56 yang sudah banyak 
mencapai ketuntasan minimum dengan presentase pencapaian sebesar $72 \%$.

2. Hasil belajar siswa dianalisis dengan menggunakan persentase ketuntasan belajar dari hasil perhitungan didapatkan 9 siswa mendapatan nilai dibawah ketuntasan minimum dan 23 siswa mendapatkan nilai sama dan diatas kriteria ketuntasan minimum kelas. Hasil perhitungan persentase ketuntasan dari $12,5 \%$ dari nilai pretest meningkat pada kuis 1 dengan persentase $18,75 \%$, pada kuis 2 dengan persentase $31,25 \%$, pada kuis 3 dengan presentase $50 \%$ dan padan posttest dengan persentase peningkatan ketuntasan siswa mencapai $72 \%$. Pembelajaran dengan menggunakan Model pembelajran Koperatif Tipe STAD setelah dilakukan evaluasi dan melihat hasil belajar siswa, dapat meningkatkan ketuntasan hasil belajar siswa pada mata pelajaran Memahami Pengukuran Kom ponen Elektronika di SMK Muhammadiyah 1 Padang.

\section{DAFTAR PUSTAKA}

[1] Abdul Majid. Strategi Pembelajaran. Bandung: Remaja Rosdakarya. (2015).

[2] Robert, E. Slavin.. Cooperative Learning Teori, Riset dan Praktek (Penerjemah: narulita Yusron). Bandung: Nusa Media. (2005).

[3] Sugiyono. (2015). Metode Penelitian Pendidikan. Bandung : Alfabeta.

[4] Tukiran Taniredja,, dkk. Model-Model Pembelajaran Inovatif dan Efektif. Bandung: Alfabeta. (2014)

[5] Trianto. Mendesain Model Pembelajaran Terpadu Konsep, Strategi, dan Implementasinya dalam Kurikulum Tingkat Satuan Pendidikan (KTSP). Jakarta: PT Bumi Aksara. (2013)

[6] Eliza, Fivia, Syamsuarnis, D.E. Myori, Hamdani, "Pembelajaran Berbasis Proyek Pada Mata Diklat Instalasi Penerangan Listrik Bangunan Sederhana". Invotek: Jurnal Inovasi Vokasional dan teknologi. vol. 17, no. 1, p. 1-10, apr. 2017.

\section{Biodata Penulis}

Hambali. lahir Pada tanggal 08 Mei 1962 Sarjana Pendidikan Teknik Elektro IKIP Padang, Memperoleh gelar Magister Kesehatan di Universitas Gadjah mada. Staf Pengajar di Jurusan Teknik Elektro FT UNP.
Fivia Eliza, lahir di Seleman (Kerinci), 07 Agustus 1985. Sarjana Pendidikan di Jurusan Teknik Elektro FT UNP 2007. Tahun 2009 memperoleh gelar Magister Pendidikan di jurusan Teknologi Pendidikan Program Pascasarjana UNP dengan bidang konsentrasi Pendidikan Kejuruan. Staf pengajar di jurusan Teknik Elektro FT UNP sejak tahun 2009- sekarang.

Yudi Andika, lahir di Paninggahan (Kab.Solok) 20 Mei 1995. Sarjana Pendidikan Teknik Elektro FT UNP 2017. 